\title{
Improving wastewater Quality of a Fish farm in Itacuruba, Northeastern Brazil
}

\author{
Érika Alves Tavares Marques ${ }^{1 *}$, Gilberto Queiroz De Lima Filho², Cláudia Ricardo De Oliveira ${ }^{1}$, Maristela \\ Casé Costa Cunha ${ }^{3}$, Silvana Carvalho De Souza Calado ${ }^{4}$ and Maria Do Carmo Martins Sobral ${ }^{1}$ \\ ${ }^{1}$ Department of Civil Engineering, Brazil \\ ${ }^{2}$ Department of Development and Environment, Brazil \\ ${ }^{3}$ Department of Education, Brazil \\ ${ }^{4}$ Department of Chemistry Engineering, Brazil
}

*Corresponding author: Érika Alves Tavares Marques, Department of Civil Engineering, Federal University of Pernambuco, Brazil.

Received Date: April 24, 2019

Published Date: May 10, 2019

\begin{abstract}
Itacuruba has ideal climate to install fish farms with a production capacity of about 100,000 tonnes per year. Located in the semiarid region where rainfall regime is extremely irregular, it is necessary to adopt strategies to improve the water use efficiency. The objective of this paper is to discuss about the efficiency of a constructed wetland (CW) on outlet water quality of a fish farm located in the Brazilian semiarid region. The system consists of an excavated tank using two aquatic macrophytes: Eichhornia crassipes and Egeria densa, which are endemic in the region. Water samples were taken from April 2015 to March 2016 for physical and chemical analysis of parameters during dry and rainy seasons. The results were compared with current legislation. During the rainy season, the maximum removal efficiency for total phosphorus was 78\%, while for total nitrogen it was $35 \%$. During the dry season, the maximum removal efficiency for phosphorus was $43 \%$ while for total nitrogen it was $53 \%$. These results reveal that a constructed wetland is a viable alternative to improve the outlet quality of a fish farm, but it requires a complementary treatment system to achieve a satisfactory result.
\end{abstract}

Keywords: Constructed wetland; Removal efficiency; Phytoremediation; Water quality; Sub-middle

Abbreviations: RW, $\mathrm{Ww}_{\mathrm{in}}$ And $\mathrm{Ww}_{\mathrm{w}}$-Sampling Points; RG-Ranges; AT-Air Temperature; WT-Water Temperature; Rain-Rainfall; EC-Electrical Conductivity; TDS-Total Dissolved Solids; TP-Total Phosphorus; SRP-Soluble Reactive Phosphorus; AN-Ammoniacal Nitrogen; TN-Total Nitrogen; DO-Dissolved Oxygen; NTU- Turbidity). MPV: Maximum Permissible Values; SD-Standard Deviation; Daily Air Temperatures On The Day Of The Monitoring (Between 08:00H And 10:00H).

\section{Introduction}

The Sub-Middle region of the São Francisco River features exceptional conditions for pisciculture in terms of water resources, regarding both volume and quality. Attracted by the warm climate and the $820 \mathrm{~km}^{2}$ Itaparica Reservoir, the region has become a major aquaculture production area in Brazil, reaching 36 thousand tonnes per year [1]. The development of the aquaculture sector has proved to be an alternative source of income for families, improving their quality of life. In addition, it contributes an alternative supply to the regional market, reducing the negative effects of fishing on local rivers [2]. However, as aquaculture assumes greater significance as a global food production system, concerns about its environmental and social impacts have arisen. As in other animal production sectors, several aquaculture inputs-land, freshwater, feed and energy-are associated with significant environmental impacts. At the same time, the availability of these inputs is limited, and will likely become even more so in the future. In addition, water pollution, fish diseases, and escapes continue to compromise the sustainability of the sector [3].

The inappropriate discharge of industrial outlets and wastewater into the environment are causes of public concern as well as grounds for legal sanctions according to current Brazilian legislation [4]. Brazil has experienced recent changes in its National Aquaculture Legislation, which incorporate principles such as public participation, shared responsibilities and recognition of traditional knowledge of fishermen [5]. 
At Brazilian scale, freshwater fish farming is essentially regulated through Conama 430 [6] which complements and alters Resolution 357 [7] from the National Council of Environment and aims at achieving good chemical and ecological status of the rivers. Conama Resolution 357/2005 determines the classification of water bodies and environmental guidelines for its framing, as well as the conditions and standards of effluents, and makes other provisions. Conama Resolution 430/2011 provides for the conditions and standards for the discharge of effluents, complements and alters Resolution 357, dated March 17, 2005, from the National Environment Council-CONAMA.

In traditional flow-through aquaculture systems water passes through the land-based tanks only once before being discharged back into the aquatic environment. The flow of water through the culture system supplies oxygen to the fish and carries dissolved and suspended wastes out of the system [8]. Water is taken from a river, circulated through the farm and treated before being released downstream. In this sense, land-based systems can be a mitigation strategy over in-lake net-cages for aquaculture farms.

According to the report Opportunities and challenges for aquaculture in developing countries [9], aquaculture is not simply a matter of producing fish -the practice is part of a complex value chain that is itself influenced by a range of environmental, societal and governmental factors that together determine a successful or failed initiative. Waite et al. [3] emphasized that aquaculture not only consumes freshwater, but also can cause freshwater pollution. Discharges from aquaculture can contain excess nutrients from fish feed and waste, antibiotic drugs, inorganic fertilizers, and a variety of chemicals (e.g. pesticides, hormones, antifoulants), contributing significantly to water quality degradation and eutrophication around the projects. Despite these effects, no treatment-or even adequate wastewater management practices - occurs in many regions throughout Brazil, leading to negative impacts on the environment $[10,11]$.

Brazilian Northeast presents problems of water scarcity and there are conflicts between multiple uses of water. According to International Panel on Climate Change [12], the region will suffer a decrease in water resources due to climate change: it will tend to become more arid, presenting an increase in the frequency and the intensity of droughts and consequent reductions in resource availability of water resources. Access to water of adequate quality is seen as essential in the production process in semiarid regions [13]. Changes in climate values do have an impact on hydrological processes and the water regime [14]. Semiarid regions are more vulnerable to eutrophication and its negative effects on water bodies, especially during periods of severe drought, as occurred during the present study. There are few studies about the use of constructed wetlands in semiarid regions, especially in Brazilian semiarid.

In this rapidly growing and maturing industry, adaptive management will be important to ensure economic, social and environmental sustainability [3]. Considering the typical water limitation in the region, it is extremely necessary to adopt ecoefficient measures in order to minimize the impacts of pisciculture on receiving water bodies. While the amount of water needed is great, fish farming also allows for its reuse. This is crucial for water-scarce areas such as the semiarid region of Brazil, where aquaculture can be integrated with agriculture by potentially using the outlet from fish farms to irrigate crops [15]. It is therefore necessary to develop more efficient wastewater treatment systems in intensive aquaculture to achieve sustainability. Among these systems, constructed wetlands are considered a well-established and low-cost method of wastewater treatment. The use of wetlands for remediation of polluted soils and waters has been increasing steadily over the past decades [16]. This technology can be used in developed and developing countries [17], improving water-quality, providing flood control, among other benefits [18].

Sezerino et al. [19] reported that wastewater treatment technology using CW was first implemented in Germany by Kathe Seidel from the Max Planck Institute in the 1950s for phenol removal and organic load reduction from dairy wastewaters [20]. In Brazil, the first experiments that used wetlands to improve water quality and control pollution were carried out in the early 1980s by Salati-Jr, et al. [21]. The concept of Green Liver Systems (GLS) was developed by [22], who pointed out the similarities between the techniques of animal and plant biotransformation [23]. GLS can be regarded as CWs, which can be used for aquaculture wastewater treatment. Depending on the type of waste to be removed, the plant(s) used may vary [24].

The first pilot project of a GLS was built in a water treatment plant on Chao Hu Lake (Hefei, China) and consists of 6 compartments: $1+2$ covered with Lemna minor; $3+4$ planted with Ceratophyllum demersum; and 5+6 planted with Phragmites Australis [23]. The second GLS pilot project is this current experiment within the INNOVATE Project (binational research project between German and Brazilian researchers that had one focus on the entire watershed of the São Francisco River and another one on a portion of the watershed -the Itaparica Reservoir aimed at suggesting practices and pathways towards ecologically and socioeconomically sound management of land, water and biodiversity. It ran from January 2012 through December 2016). The GLS was used for treating aquaculture wastewater, according to legislation on water quality.

Wastewater treatment systems using macrophytes are a feasible alternative for fish farmers to minimize negative impacts on aquatic ecosystems. Although many studies have demonstrated the efficiency of aquatic plants for treating aquaculture wastewaters in Brazil [10,11,25-28] there are relatively few studies investigating the use of this technique in Brazil's semiarid Northeast $[29,30]$. Therefore, more studies are required to evaluate the potential and feasibility of phytoremediation processes using Eichhornia crassipes and Egeria densa by GLS in the region. The objective of this paper is to discuss about the efficiency of a CW on outlet water quality of a fish farm located in the Brazilian semiarid region. 


\section{Methods}

\section{Location description}

This study was carried out at a fish farm located on the shore of the Itaparica Reservoir in the municipality of Itacuruba $\left(08^{\circ} 50^{\prime} 22.50^{\prime \prime} \mathrm{S}\right.$ and $\left.38^{\circ} 41^{\prime} 47.38^{\prime \prime} \mathrm{W}\right)$, State of Pernambuco, northeastern Brazil (Figure 1). Itacuruba has 4,369 inhabitants according to the last census of the Brazilian Geographical and Statistical Institute [31] (Figure 1).
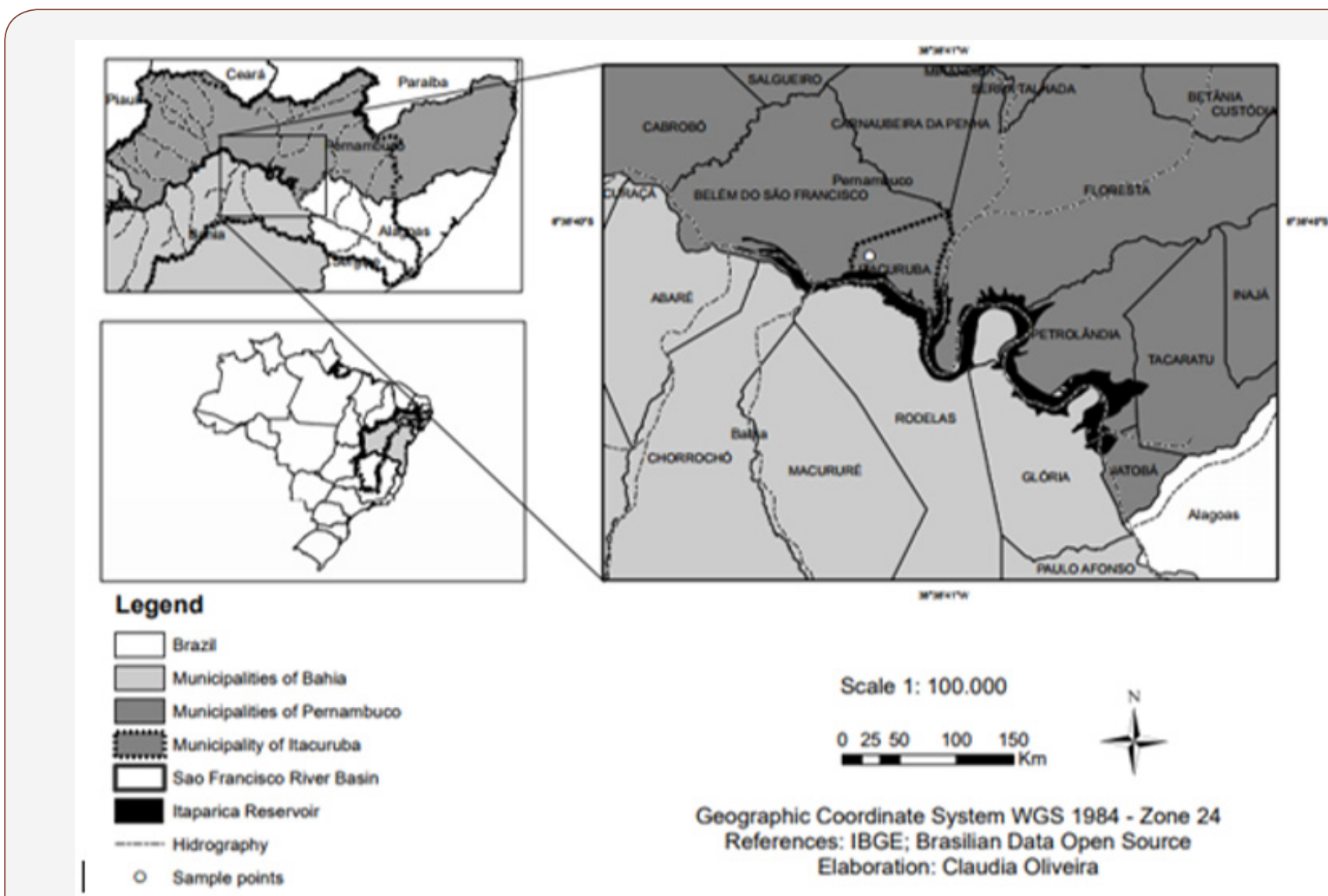

Figure 1: Detail of a map of Brazil highlighting the State of Pernambuco, sampling points and the Itaparica Reservoir.

As stated by Melo (2007) [32], the Itaparica Reservoir is located between the Brazilian states of Pernambuco and Bahia, in the physiographic region designated as the Sub-Middle São Francisco and was built in 1987 for the primary purpose of electricity generation. The reservoir, however, provides for multiple uses including public and industrial water supply, irrigation, pisciculture, livestock, tourism and leisure.

The municipality of Itacuruba covers an area of $430,000 \mathrm{~km}^{2}$ and is in the Pajeú River Basin within the Sub-Middle Sao Francisco and features a hot semiarid climate with a mean annual temperature of $26.1^{\circ} \mathrm{C}$ [31]. According to the classification of Köppen [33], its climate is classified as BSwh (B -arid climate; S - weather of the steppes; $w$-with a wet season in the summer that may not occur; $h$ -dry and hot). The vegetation is characterized as hyper xerophilic Caatinga [34].

As a small municipality, Itacuruba's economy relies on pisciculture in excavated tanks and net-cages, as well as the use of drylands for livestock and subsistence agriculture [35]. Belfort [36] reported that ten years ago, a group of 12 people were producing a few kilograms of fish in the Itaparica Reservoir. Today, there are 96 fish farmers who together produce 100 tonnes of tilapia per month.
This multiplication occurred because of a simple fact: the producers grouped together in associations, which now number eight. They then formed a cooperative and later a Local Productive Arrangement - a structure that attempts to bring together a production cluster in a coordinated form: the production of fingerlings and the fattening of tilapia (primary sector); manufacture of aquaculture structures and factories for both fish feed and ice for processing (secondary sector); marketing and services (tertiary sector) [37].

Kubitza [38] noted that the great vocation and market potential created by the aquaculture sector attracts domestic and international investors interested in fish farming and several other segments of the production supply chain, especially fish feed, medicines, vaccines, genetics and equipment. The fish farm where the experiment took place operates under an intensive production system, with six excavated $1,200 \mathrm{~m}^{3}$ tanks for juvenile tilapia (Oreochromis niloticus) production, as well as two excavated tanks of $1,600 \mathrm{~m}^{3}$ and nine excavated tanks of $1,800 \mathrm{~m}^{3}$. The tanks are supplied with $75,000 \mathrm{~L}$ water under a continuous flow rate and water renewal is every 10 to 15 days. Excavated tanks of $6,000 \mathrm{~m}^{3}$ are dedicated to the production of tambaqui (Colossoma macropomum Cuvier 1816). 
Wastewater treatment was carried out in a horizontal subsuperficial flow CW (named as GLS) $100 \mathrm{~m} \times 25 \mathrm{~m}$ x $2.0 \mathrm{~m}$ in size, with six baffles of $0.4 \mathrm{~m} \times 20 \mathrm{~m}$ (Figure 2). During the rainy season, mean outflow was $3.03 \mathrm{Lmin}^{-1}$; during the dry season it was $2.05 \mathrm{Lmin}$ ${ }^{1}$. The hydraulic retention time (HRT) of wastewater was at least $72 \mathrm{hrs}$, with an operating volume of $1,200 \mathrm{~m}^{3}$. The GLS was divided into six sections, with the first treatment stage (first $30 \mathrm{~m}$ after the inlet) using Eichhornia crassipes (popularly known as aguapé), a floating plant. The remainder of the tank was planted with Egeria densa, a submerged rooted species. E. crassipes removes high concentrations of nutrients and its roots form a dense biomass that retains solids, thus reducing turbidity; for this reason, it is placed near the system input (Figure 2).

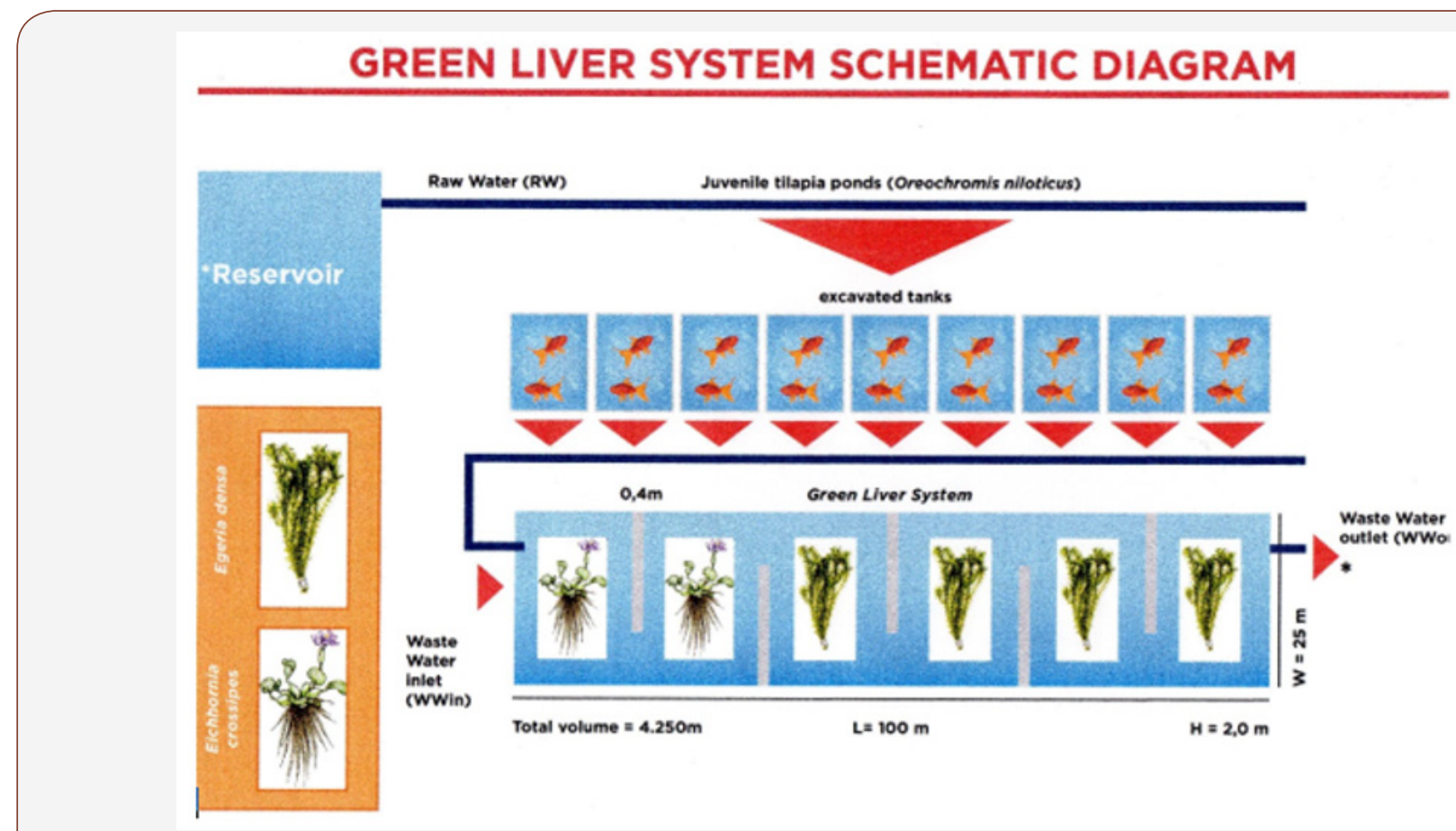

Figure 2: Schematic diagram of the Green Liver System.

\section{Macrophyte establishment}

The GLS was introduced in August 2013. Due to the initial turbidity of the water column, the aquatic plants were first installed after a period of 60 days. For a more efficient treatment process, young samples of E. crassipes and E. densa were taken from an oxbow lake due to their higher productivity at this stage of development. In the first stage was installed E. crassipes, covering about $60 \%$ of the water surface. In the remaining $70 \mathrm{~m}$ of the wetland was installed 25 seedlings of E. densa per $\mathrm{m}^{2}$. Management of the macrophytes was done monthly.

\section{Field sampling and analysis}

From April 2015 to March 2016, twelve water samples were collected from five sampling points in the morning (totalizing 60 samples), to monitor physical and chemical water quality parameters and the efficiency of the GLS system. The dry season at the time of sampling ( $\mathrm{n}=9$ ) was from April to December 2015 and the rainy season $(n=3)$ was from January to March 2016. The samples were collected monthly from raw water and outlet subsurface in triplicate. The raw water sampling point (RW) was in the Itaparica Reservoir between coordinates S $08^{\circ} 48^{\prime} 21.27^{\prime \prime}$ and W $038^{\circ} 44^{\prime 26.18}$ ". The wastewater inlet (WWin) of the GLS was located between the coordinates S $08^{\circ} 48.302^{\prime}$ 'S and W $038^{\circ} 44^{\prime} 29.2^{\prime \prime}$. The wastewater outlet (WWout) of GLS was located between coordinates S $08^{\circ} 48.357^{\prime}$ and W $038^{\circ} 44^{\prime} 35^{\prime \prime}$.
The air temperature $\left(\mathrm{AT},{ }^{\circ} \mathrm{C}\right)$ was measured using a thermometer; water temperature $\left(\mathrm{WT},{ }^{\circ} \mathrm{C}\right), \mathrm{pH}$, electrical conductivity (EC, $\mu \mathrm{Scm}-1)$, salinity (\%o) and total dissolved solids (TDS, $\mathrm{mgL}^{-1}$ ) were analyzed in situ using a multiparameter Oakton probe. The samples were kept in $250 \mathrm{~mL}$ plastic bottles, maintained at approximately $4 \mathrm{oC}$ and analysed in triplicate. Total phosphorus (TP, $\mathrm{mg} \mathrm{L}^{-1}$ ), soluble reactive phosphorus (SRP, $\mathrm{mgL}^{-1}$ ), total nitrogen ( $\left.\mathrm{TN}, \mathrm{mgL}^{-1}\right)$, ammoniacal nitrogen ( $\left.\mathrm{AN}, \mathrm{mgL}^{-1}\right)$, nitrite $\left(\mathrm{mgL}^{-1}\right)$ and nitrate $\left(\mathrm{mgL}^{-1}\right)$, dissolved oxygen (DO, $\mathrm{mgL}^{-1}$ ) and turbidity (NTU) were analysed in the laboratory of the Chemistry Department at the Federal University of Pernambuco. TP, SRP, nitrite and nitrate were analysed according to Golterman et al. (1978) [39]; AN was analysed according to Koroleff [40]; DO was analysed according to Winkler (1988) [41] and turbidity was analysed using Nephelometric methodology.

Water samples were collected from below the surface in clean plastic or glass $500 \mathrm{~mL}$ bottles previously washed with the same water to be collected. For the evaluation of some specific parameters, the samples were maintained at a $\mathrm{pH}<2$. The National Council for the Environment (CONAMA) sanctioned Resolution 430 [6], which classifies water bodies, establishes limit levels of wastewater discharge, complements and alters Resolution 357 [7]. This was used to compare the Maximum Permissible Values (MPV) with the monitored results from the outlet to verify if the treated outlet water complied with the legislation. 


\section{Climatic parameters}

The climatic data were obtained from the Brazilian National Institute of Meteorology (INMET 2016) [42] from its Data Collection Platform (PCD) A-351 located in the municipality of Floresta, $40 \mathrm{~km}$ from Itacuruba. The mean monthly rainfall (mm) and air temperature $\left({ }^{\circ} \mathrm{C}\right)$ during wet and dry months were used to analyze the effects of seasonality (means of the periods and their standard variations).

\section{Statistical analysis}

To calculate the Mean Removal Efficiency (MRE) of nutrients and solids by the wetland, the following formula was used based on Kadlec and Wallace (2009) [43]:

MRE Wetland \%=[(WW $\left.\left.W_{\text {in }}-W W_{\text {out }}\right) / W W_{\text {in }}\right] \times 100$

where $W_{\text {in }}$ is the concentration in wastewater before treatment (inlet) and WWout is the concentration in wastewater after treatment (outlet).

Calculating the mean of the parameters was done for the dry season considering the 9-month period (April to December 2015) and the rainy season considering the 3-month period (January to March 2016). Statistical analysis was carried out using the IBM Statistica 23 software. All data were tested for normality of distribution with the Shapiro-Wilk test. The parametric data were statistically subjected to ANOVA. When significant differences were observed among means, the Tukey test HSD ( $p$ > 0.05) was applied using the IBM Statistica 23 software.

\section{Result}

\section{Physicochemical parameters}

Air temperature varied between $23.5^{\circ} \mathrm{C}$ during the dry period (April to December 2015) and $45.4{ }^{\circ} \mathrm{C}$ during the rainy period (January to March 2016). The rainy season in Itacuruba begins in January and finishes in April, being this period rainier. Rainfall occurs in summer, and winters, in most of the area, are dry. The strong irradiation during rainy season, coupled with the low relative humidity, conditions a high potential evapotranspiration, whose annual average is $2,042 \mathrm{~mm}$. Water temperature varied between $22.7{ }^{\circ} \mathrm{C}$ and $31.4{ }^{\circ} \mathrm{C}$ in the dry and rainy seasons, respectively, tolerable for both macrophytes. According to INMET (2016) [42], the accumulated rainfall during the dry season was $281 \mathrm{~mm}$ and $342 \mathrm{~mm}$ in the rainy season.

In accordance with CONAMA Resolution 357 [7], Class 2 freshwater in Lake Itaparica can be used for aquaculture and fishing activity. The $\mathrm{pH}$ of the water was in accordance with the Resolution's limits (between 6 and 9) in all samples. The electrical conductivity was $77.70 \mu \mathrm{S} \mathrm{cm}^{-1}$, salinity was $43.9 \%$ and TDS were $42.76 \mathrm{mg} \mathrm{L}^{-1}$. CONAMA Resolution 430 does not establish any limit for salinity or SRP. Waters with salinity that are equal or superior to $30 \%$ are considered as Saltwater by Conama Resolution 357. In the semi-arid region, the reservoirs are subject to high evaporation rates, becoming salty, reaching, in some cases, concentrations of salts that prevent its use for human consumption and agriculture.
Raw water TP concentrations varied between $0.02 \mathrm{mgL}^{-1}$ to 20 $\mathrm{mgL}^{-1}$ Wastewater TP concentrations remained high at both points (Fig. 3) both in the dry period and in the rainy season in relation to the limit recommended by CONAMA Resolution 357 [7] ( $\geq 0.03$ $\mathrm{mgL}^{1}$ for lentic environments). Semi-arid reservoirs are highly vulnerable to eutrophication, due to their large catchment to surface area ratio and high-water residence time, which points their potential for high retention of nutrients and sediments exported from the watershed [45]. Additional phosphorus from uneaten fish feed also contributes to the high concentrations of phosphorus in the wastewater. In semiarid regions this impact, associated with elevated temperatures and high evapotranspiration, is even more intense. The highest concentrations of TP occurred at $\mathrm{WW}_{\text {in }}$ and $\mathrm{WW}_{\text {out }}$ in January 2016 (both presenting $0.47 \mathrm{mgL}^{-1}$ ). SRP varied between $0.02 \mathrm{mgL}^{-1}$ and $0.10 \mathrm{mgL}^{-1}$ after the treatment (Figure 3).

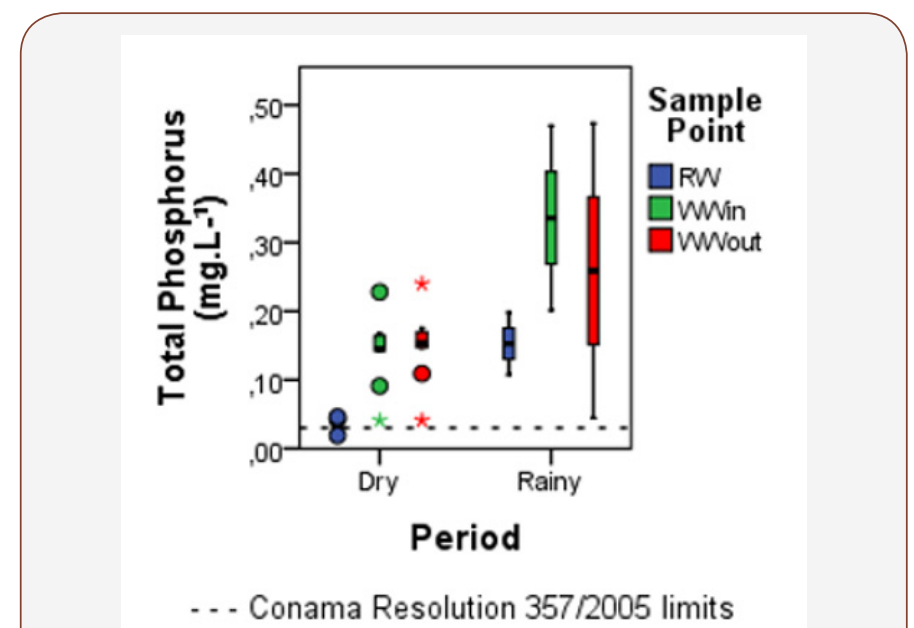

Figure 3: Boxplot of total phosphorus seasonal variation from sampling points during dry and rainy seasons.

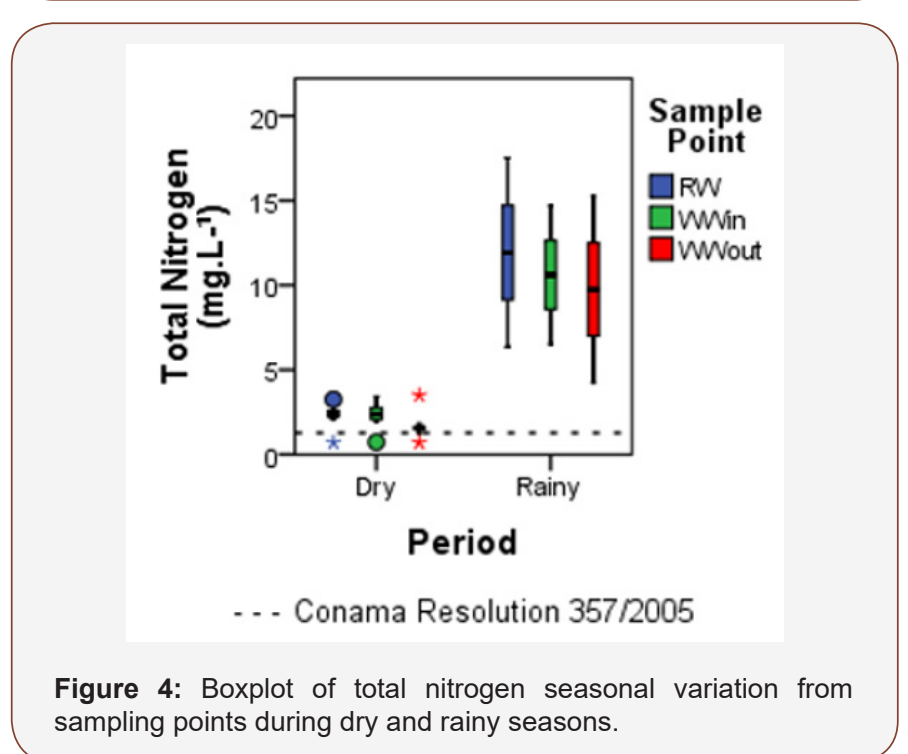

Total nitrogen (TN) concentrations presented values above CONAMA Resolution 430 [6] ( $\geq 1.27 \mathrm{mgL}^{-1}$ for lentic environments) in all samples, with exception of the sample collected in April/2015 (Figure 4). Raw water concentrations of TN reached $3.25 \mathrm{mgL}^{-1}$ and $17.51 \mathrm{mgL}^{-1}$ in the dry and rainy seasons, respectively. The highest TN concentration occurred during March 2016 (21.18mgL $\left.{ }^{-1}\right)$. The 
wetland promoted efficient removal for TN during both periods, with exception of the sample collected in April 2015 (-40.0\%). About total nitrogen, the outflow suffered more influence from the raw water than from the pisciculture. All samples presented low values for ammoniacal nitrogen (between $3.7 \mathrm{mgL}^{-1}$ for $\mathrm{pH} \leq 7.5$ and $1.0 \mathrm{mgL}^{-1}$ for $\left.\mathrm{pH} 8.0<\mathrm{pH} \leq 8.5\right)$, nitrite $\left(\leq 1 \mathrm{mgL}^{-1}\right)$, nitrate $(\leq 10 \mathrm{mgL}$ $\left.{ }^{1}\right)$ during the studied period and were in accordance with the law) (Figure 4).

Regarding Dissolved Oxygen (D0), $88 \%$ of the samples presented values below the CONAMA Resolution 430 limit [6] $\left(\geq 5.0 \mathrm{mgL}^{-1}\right)$. For turbidity (NTU) all samples were according to law $\left(<100 \mathrm{mgL}^{-1}\right)$. Mean concentration of total phosphorus did not indicate statistical differences between sampling points, aside from point RW that corresponds to raw water from the Itaparica Reservoir ( $p$-value>0.05). Mean concentration of TN showed statistical differences between all sampling points. The mean values of the physicochemical parameters monitored in Itaparica Reservoir (point RW) and the wetland $\left(\mathrm{WW}_{\mathrm{in}}, \mathrm{WW}_{\text {out }}\right.$ ), their respective ranges and the maximum values established by CONAMA Resolution 357 [7] for Class 2 rivers are shown in (Table 1).

Table 1: Results of the parameters monitored in the Green Liver System (wetland) and standard deviation of the mean during dry period and rainy seasons (RW, WWin and SSWout -Sampling Points; RG-Ranges; AT-air temperature; WT-water temperature; Rain-rainfall; EC-electrical conductivity; TDS-total dissolved solids; TP-total phosphorus; SRP-soluble reactive phosphorus; AN-ammoniacal nitrogen; TN-total nitrogen; DO-dissolved oxygen; NTU-Turbidity)

\begin{tabular}{|c|c|c|c|c|c|c|c|}
\hline \multirow{2}{*}{ Parameter } & \multicolumn{7}{|c|}{ Dry season - mean season rainfall $10.8 \mathrm{~mm}(\mathrm{n}=9)$} \\
\hline & $\begin{array}{l}\text { Raw Water } \\
\text { (RW) }\end{array}$ & SD & $\begin{array}{l}\text { Wastewater Inlet } \\
\text { (WWin) }\end{array}$ & SD & $\begin{array}{c}\text { Wastewater } \\
\text { outlet (WWout) }\end{array}$ & SD & $\begin{array}{l}\text { MVP by CONAMA Resolution } 357 \\
\text { (2005) }\end{array}$ \\
\hline Daily AT $\left({ }^{\circ} \mathrm{C}\right)^{*}$ & 32.3 & 1.01 & 33.63 & 1.74 & 33.95 & 1.11 & --- \\
\hline WT $\left({ }^{\circ} \mathrm{C}\right)$ & 27.81 & 0.66 & 26.91 & 0.8 & 27.41 & 0.98 & $40 \stackrel{\circ}{ } \mathrm{C}$ \\
\hline $\mathrm{pH}$ & 7.61 & 0.21 & 6.65 & 0.18 & 7.78 & 0.17 & $6 \leq \mathrm{pH}<9$ \\
\hline $\mathrm{EC}\left(\mu \mathrm{S} . \mathrm{cm}^{-1}\right)$ & 98.34 & 6.05 & 118.06 & 10.23 & 94.85 & 3.87 & $100 \mu{\mathrm{S} . \mathrm{cm}^{-}}^{1}$ \\
\hline Salinity $(\% 0)$ & 59.52 & 3.8 & 71.41 & 5.53 & 59.02 & 3.51 & --- \\
\hline TDS $\left(m g \cdot L^{-1}\right)$ & 63.21 & 5.05 & 76.27 & 7.1 & 61.63 & 4.95 & 500 mg.L- ${ }^{1}$ \\
\hline TP (mg.L- $\left.{ }^{-1}\right)$ & 0.06 & 0.02 & 0.19 & 0.03 & 0.18 & 0.03 & $0.03 \mathrm{mg.L-}^{1}$ \\
\hline SRP $\left(m g . L^{-1}\right)$ & 0.05 & 0.01 & 0.08 & 0.01 & 0.01 & 0 & --- \\
\hline Nitrite (mg.L- ${ }^{-1}$ ) & 0.19 & 0.06 & 0.05 & 0.02 & 0.02 & 0 & $1.0{\mathrm{mg} . \mathrm{L}^{-1}}^{1}$ \\
\hline Nitrate (mg.L- ${ }^{1}$ ) & 0.02 & 0 & 0.05 & 0.01 & 0.04 & 0.01 & 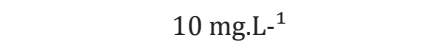 \\
\hline AN (mg.L- $\left.{ }^{-1}\right)$ & 0.22 & 0.06 & 0.27 & 0.06 & 0.15 & 0.03 & $\begin{array}{c}3.7 \mathrm{mg} \cdot \mathrm{L}-^{-1} \mathrm{~N}, \text { if pH } \leq 7.52 .0 \mathrm{mg} \cdot \mathrm{LL}^{-1} \mathrm{~N} \\
\text { if } 7.5<\mathrm{pH} \leq 8.01 .0 \mathrm{mg} \cdot \mathrm{LL}^{-1} \mathrm{~N}, \text { if } 8.0< \\
\mathrm{pH} \leq 8.5 \quad 0.5 \mathrm{mg} \cdot \mathrm{L}^{-1} \mathrm{~N}, \text { if } \mathrm{pH}>8.5\end{array}$ \\
\hline TN (mg.L- $\left.{ }^{-1}\right)$ & 4.74 & 1.44 & 4.46 & 1.2 & 3.69 & 1.27 & 1.27 mg.L- ${ }^{1}$ \\
\hline DO (mg.L- $\left.{ }^{-1}\right)$ & 6.77 & 0.92 & 6.63 & 1.31 & 3.68 & 0.41 & $\geq 5 \mathrm{mg} \cdot \mathrm{L}-/^{1}$ \\
\hline Turbidity (NTU) & 21.95 & 1.93 & 30.09 & 6.06 & 27.68 & 1.63 & $100 \mathrm{NTU}$ \\
\hline \multicolumn{8}{|c|}{ Rainy season-mean season rainfall $40.5 \mathrm{~mm}(n=3)$} \\
\hline Daily AT $\left({ }^{\circ} \mathrm{C}\right)^{*}$ & 36.03 & 2.54 & 40.73 & 1.16 & 38.53 & 3.66 & --- \\
\hline WT $\left({ }^{\circ} \mathrm{C}\right)$ & 29.8 & 0.23 & 29.7 & 0.87 & 30 & 0.58 & $40 \stackrel{\circ}{ } \mathrm{C}$ \\
\hline $\mathrm{pH}$ & 7.43 & 0.23 & 7.3 & 0.21 & 8.21 & 0.3 & $6 \leq \mathrm{pH}<9$ \\
\hline $\mathrm{EC}\left(\mu \mathrm{S} . \mathrm{cm}^{-1}\right)$ & 141.08 & 7.73 & 179.88 & 11.19 & 127.55 & 8 & $100 \mu$ S.cm- $^{1}$ \\
\hline Salinity $(\% 0)$ & 75.12 & 4.01 & 84.7 & 10.04 & 68.65 & 3.75 & --- \\
\hline TDS $\left(m g . L^{-1}\right)$ & 88.48 & 6.31 & 100.87 & 11.49 & 82.27 & 7.14 & 500 mg.L- ${ }^{1}$ \\
\hline TP (mg.L- $\left.{ }^{-1}\right)$ & 0.15 & 0.03 & 0.27 & 0.08 & 0.26 & 0.12 & 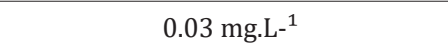 \\
\hline SRP $\left(m g . \mathrm{LL}^{-1}\right)$ & 0.11 & 0.03 & 0.1 & 0.01 & 0.01 & 0.01 & --- \\
\hline Nitrite (mg.L- ${ }^{1}$ ) & 0.27 & 0.07 & 0.1 & 0.02 & 0.03 & 0.01 & $1.0{\mathrm{mg} . \mathrm{L}^{-}}^{1}$ \\
\hline Nitrate (mg.L-1 ${ }^{1}$ ) & 0.03 & 0.01 & 0.06 & 0.02 & 0.07 & 0.02 & $10{\mathrm{mg} . \mathrm{L}^{-}}^{1}$ \\
\hline AN $\left(\mathrm{mg} \cdot \mathrm{L}^{-1}\right)$ & 0.3 & 0.27 & 0.29 & 0.18 & 0.25 & 0.11 & $\begin{array}{c}3.7 \mathrm{mg} \cdot \mathrm{L}^{-1} \mathrm{~N}, \text { if } \mathrm{pH} \leq 7.52 .0 \mathrm{mg} \cdot \mathrm{L}^{-1} \mathrm{~N} \\
\text { if } 7.5<\mathrm{pH} \leq 8.01 .0 \mathrm{mg} \cdot \mathrm{L}^{-1} \mathrm{~N} \text {, if } 8.0< \\
\mathrm{pH} \leq 8.50 .5 \mathrm{mg} \cdot \mathrm{L}^{-1} \mathrm{~N}, \text { if } \mathrm{pH}>8.5\end{array}$ \\
\hline $\mathrm{TN}\left(\mathrm{mg} \cdot \mathrm{L}^{-1}\right)$ & 11.93 & 3.22 & 8.14 & 2.98 & 9.75 & 3.18 & $1.27 \mathrm{mg} . \mathrm{L}^{-1}$ \\
\hline DO (mg.L-1 $\left.{ }^{-1}\right)$ & 8.01 & 3.24 & 7.09 & 2.93 & 5.06 & 0.96 & $\geq 5 \mathrm{mg} \cdot \mathrm{L}-/^{1}$ \\
\hline Turbidity (NTU) & 25.8 & 3.41 & 37.05 & 16.42 & 25.2 & 0.98 & $100 \mathrm{NTU}$ \\
\hline
\end{tabular}

MPV: Maximum Permissible Values; SD-Standard Deviation; *Daily air temperatures on the day of the monitoring (between 08:00h and 10:00h). 


\section{Evaluation of the mean removal efficiency (MRE) of the} GLS

The wastewater treatment with E. crassipes and E. densa showed better removal efficiency during the rainy period for total dissolved solids, total phosphorus (Figure 5), nitrite, nitrate and turbidity possibly due to the dilution of nutrients and organic matter by rainfall. During the dry period, the treatment system showed better removal efficiency for SRP, ammoniacal nitrogen and total nitrogen (Figure 5\&6) (Table 2).

Table 2: Minimum, maximum, mean and the standard deviation of the removal efficiencies of the nutrients during the dry and rainy seasons (RGranges; EC-electrical conductivity; TDS-total dissolved solids; TP-total phosphorus; SRP-soluble reactive phosphorus; AN-ammoniacal nitrogen; TNtotal nitrogen; DO-dissolved oxygen) in the Green Liver System; SD-Standard Deviation of mean values.

\begin{tabular}{|c|c|c|c|c|c|c|c|c|}
\hline \multicolumn{9}{|c|}{ Removal Efficiency (\%) } \\
\hline \multirow{2}{*}{$\begin{array}{c}\text { Parameter } \\
\text { Statistic }\end{array}$} & \multicolumn{4}{|c|}{ Dry season $(n=9)$} & \multicolumn{4}{|c|}{ Rainy season $(n=3)$} \\
\hline & Minimum & Maximum & Mean & SD & Minimum & Maximum & Mean & SD \\
\hline TDS (mg.L- ${ }^{1}$ ) & -29.3 & 52.59 & 12.36 & \pm 7.25 & 13.50 & 39.31 & 26.52 & \pm 7.45 \\
\hline TP $\left(\mathrm{mg} . \mathrm{L}^{-1}\right)$ & -542.31 & 43 & -297.52 & \pm 64.28 & -0.69 & 77.89 & 33.36 & \pm 23.28 \\
\hline SRP (mg.L- ${ }^{1}$ ) & 77.98 & 97.91 & 90.73 & \pm 1.98 & 80.8 & 96.98 & 88.89 & \pm 4.67 \\
\hline Nitrite (mg.L-1) & -150 & 84.92 & -24.32 & \pm 30.55 & 66.56 & 83.55 & 73.74 & \pm 5.08 \\
\hline Nitrate (mg.L- ${ }^{1}$ ) & -766.67 & 68.42 & -59.02 & \pm 89.31 & -83.33 & 70 & 6.14 & \pm 46.08 \\
\hline NA (mg.L- $\left.{ }^{1}\right)$ & -193.75 & 93.3 & 29.31 & \pm 29.25 & -504.67 & -111.29 & -274.74 & \pm 128.55 \\
\hline TN (mg.L-1) & -2.94 & 52.49 & 28.72 & \pm 5.87 & -3.88 & 35.06 & 13.1 & \pm 11.51 \\
\hline Turbidity (NTU) & -519.99 & 53.13 & -61.19 & 62.86 & -92.31 & 9.91 & -34.13 & \pm 30.47 \\
\hline
\end{tabular}

SD- Standard Deviation of mean values.

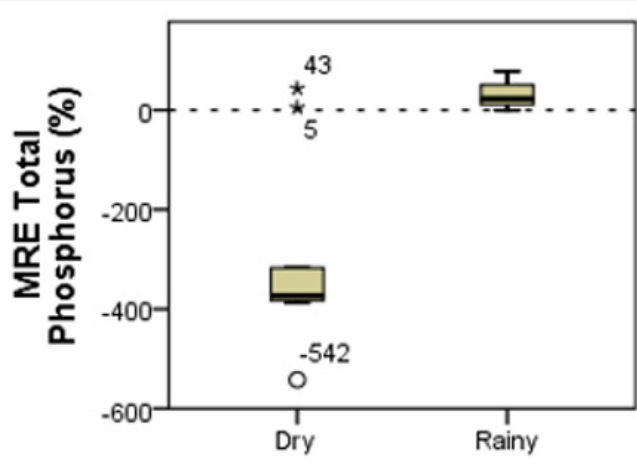

Period

Figure 5: Mean removal efficiency of total phosphorus during dry and rainy seasons.

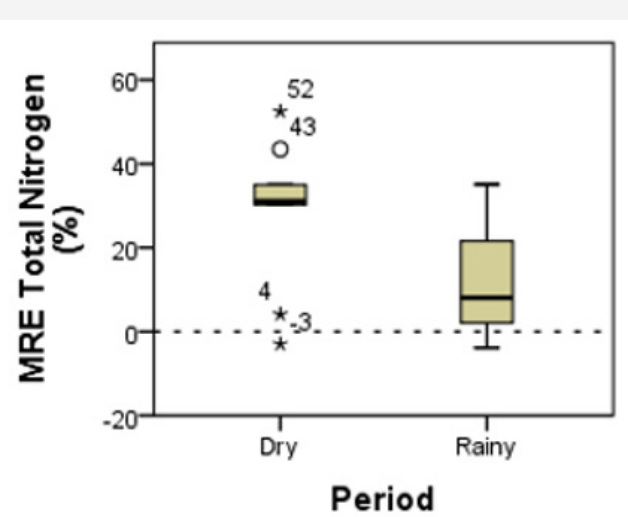

Figure 6: Mean removal efficiency of total nitrogen during dry and rainy seasons.

The concentration of total phosphorus in the outlet after the treatment system was above the maximum permissible value by CONAMA Resolution 430 (2011) during both periods due to the high concentration of this nutrient in the sediment and water column. The results showed that the wetland using E. crassipes and
E. densa promoted better MRE for total phosphorus in the rainy season (33.36\%) while for total nitrogen the best MRE occurred in the dry season $(28.72 \%)$. With respect to seasonality, analysis of variance (One-way ANOVA) showed that there was significant difference in the results of total phosphorus $(\mathrm{p}<0.005)$ between dry and rainy seasons (Table 3).

Table 3: Analysis of variance (One-way ANOVA) between the mean removal efficiencies of the nutrients and solids in the wetland according to seasonality. Total phosphorus presented significant difference $(p>0.05)$.

\begin{tabular}{|c|c|c|c|c|}
\hline Parameter & $\begin{array}{l}\text { Sum of } \\
\text { Squares }\end{array}$ & Df & $\mathbf{F}$ & Sig \\
\hline $\begin{array}{l}\text { Electrical Conductivity }(\mu S \\
\left.\mathrm{cm}^{-1}\right)\end{array}$ & 340.833 & 1 & 0.869 & 0.114 \\
\hline Salinity (ppm) & 685.742 & 1 & 1.047 & 0.33 \\
\hline $\begin{array}{l}\text { Total Dissolved Solids (mgL- } \\
1 \text { ) }\end{array}$ & 448.592 & 1 & 1.082 & 0.323 \\
\hline Total Phosphorus (mgL- ${ }^{1}$ ) & 325352.357 & 1 & 18.74 & $0.001^{*}$ \\
\hline $\begin{array}{l}\text { Soluble Reactive Phosphorus } \\
\qquad\left(\mathrm{mgL}^{-1}\right)\end{array}$ & 7.599 & 1 & 0.184 & 0,677 \\
\hline Total Nitrogen $\left(\mathrm{mgL}^{-1}\right)$ & 549.512 & 1 & 1.679 & 0.224 \\
\hline $\begin{array}{l}\text { Ammoniacal Nitrogen (mgL- } \\
1 \text { ) }\end{array}$ & 172710.892 & 1 & 10.745 & 0.008 \\
\hline Nitrite $\left(\mathrm{mgL}^{-1}\right)$ & 21635.958 & 1 & 3.213 & 0.103 \\
\hline Nitrate $\left(\mathrm{mgL}^{1}{ }^{1}\right)$ & 9553.433 & 1 & 0.163 & 0.695 \\
\hline Dissolved Oxygen (mgL-1 ${ }^{1}$ ) & 4282.612 & 1 & 0.521 & 0.487 \\
\hline Turbidity (NTU) & 1646.872 & 1 & 0.057 & 0.816 \\
\hline
\end{tabular}

*Significant difference between dry and rainy periods $(p<0.05)$.

\section{Discussion}

\section{Nutrient uptake by macrophytes}

CWs have been used worldwide for wastewater treatment [46]. Researchers have demonstrated that CW can remove significant amounts of suspended solids, organic matter, nitrogen and phosphorus from wastewater [47]. As water flows through the built 
wetland, the roots of the E. crassipes, located near the entrance to the tank, act as a barrier, slowing the water towards the receiving body, causing the sediments and pollutants it carries to precipitate. In this way, these sediments and pollutants can be captured by the vegetation and, soon after, metabolized. E. crassipes is a plant with long roots, which can reach $1 \mathrm{~m}$ in length. In its metabolic process, this species can absorb some pollutants from the water and transform them into fresh matter through photosynthesis [48]. On the other hand, E. densa has a high specific growth rate and relatively short doubling time. It occupies large tracts and accumulates about 50 tons per hectare in more colonized regions [49].

\section{Parameters results}

In this study, water temperature at the outlet of the treatment system was $0.2{ }^{\circ} \mathrm{C}$ to $4.6{ }^{\circ} \mathrm{C}$ higher than at its inlet. This result possibly arose because the part of the wetland corresponding to $\mathrm{E}$. densa (rooted macrophyte) receives radiation directly into the water column while E. crassipes causes shading and decreases the water temperature at the entrance to the wetland. Electrical conductivity was above $100 \mu \mathrm{Scm}^{-1}$ in $80 \%$ of the samples. In the rainy season electrical conductivity was higher in comparison to the dry season. Electrical conductivity is an indirect measurement of the pollutant concentration in aquatic environments [50]. Several authors have observed that in eutrophic environments electrical conductivity is elevated, with values varying from $48 \mathrm{uScm}^{-1}$ to $240 \mathrm{uScm}^{-1}$. Carvalho-Júnior et al. [51] reported that generally elevated values are related to a high rate of decomposition. According to Rotta \& Queiróz (2003) [52,53], in most cases changes in the physical and chemical parameters of water quality are caused by activities in areas adjacent to the reservoirs.

Lower $\mathrm{pH}$ values were observed in the inlet samples both in the dry season $(6.65+0.18)$ and the rainy season $(7.30+$ $0.21)$ compared to the outlet samples $(7.78+0.17$ and $8.21+$ 0.30 , respectively). Hussar et al. [53], analysing water samples from inlets and outlets of aquaculture tanks, reported the same finding. Similarly, Cavalcante \& Sá [54] noted that the water $\mathrm{pH}$ in aquariums without and with the presence of phytoplankton was $7.32 \pm 0.39$ and $8.45 \pm 0.40$, respectively with the difference being explained by the phytoplankton's capacity for removing $\mathrm{CO}_{2}$ from water during the photosynthetic process. However, Tundisi \& Tundisi (2008) [55] found that pisciculture tended to reduce $\mathrm{pH}$ in accordance with the increase in organic matter to be decomposed by heterotrophic organisms, while phytoplankton can increase $\mathrm{pH}$, as, during photosynthesis, $\mathrm{CO}_{2}$ and $\mathrm{HCO}_{3}$ are removed by primary producers.

During the dry period all DO samples at the outlet (WWout) presented low values $\left(<5 \mathrm{mgL}^{-1}\right)$. Hussar et al. [53] attributed this to oxygen use by the root systems of macrophytes as well as the nitrification process within the system. Souza et al. [56] observed that wetlands that had Spartina alternifolia macrophytes had higher levels of dissolved oxygen and $\mathrm{pH}$ in relation to wetlands that did not have macrophytes.
According to Casillas-Hernández et al. [57], only 25 to $30 \%$ of nitrogen and phosphorus supplied in food and fertilizer for aquaculture will be used for the formation of fish biomass, with the rest being retained in the sediment of the nurseries or eliminated via the outlet. Batista et al. [58] found similar results in relation to total phosphorus (TP) at the Orós Dam (Ceará, Brazil) in an area close to a fish-cleaning community that disposes a great amount of wastewater.

In the rainy season mean TP varied between $0.05 \mathrm{mgL}^{-1}$ to $0.11 \mathrm{mgL}^{-1}$; in the dry season it varied from $0.14 \mathrm{mgL}^{-1}$ to $0.13 \mathrm{mgL}^{-}$ ${ }^{1}$. [24] achieved good removal efficiency for E. crassipes with regard to nitrogen, particularly for $\mathrm{NH} 3(63.4 \%)$, but not for TP (-204.0\%), whereas biofilm was efficient in capturing TP (23.89\%). There are additional factors that may exacerbate $\mathrm{P}$ concentrations in aquaculture systems as reported by Cooke et al. [59,60]: low dissolved oxygen concentration, high temperature, shallow water and large tank surface area relative to depth. All these contribute to resuspend and re-dissolve $\mathrm{P}$ in the tanks leading to a high degree of internal P loading in addition to the external factors mentioned previously (agriculture runoff and urban/industrial discharges).

During the rainy season an increase of AN occurred presenting a MRE of -323.95\%. [61] also observed an increase in AN and nitratewhile still remaining within the values established by CONAMA Resolution 430 [6] for areas of a reservoir under tilapia farmed in net-cages systems located in Pariquera-Açú, State of São Paulo, in the regional pisciculture hub of [62] obtained a MRE between $5.6 \%$ and $93.9 \%$. It is emphasized that the raw water from the Itaparica Reservoir, which supplies the fish nurseries, already has a total nitrogen concentration above the limit allowed by legislation $\left(>1.27 \mathrm{mgL}^{-1}\right)$. Contaminated outlets, when released directly into river and lake waters, provoke potential risks to public health, especially when untreated waters are used in food preparation, personal hygiene or crop irrigation [63,64]. As shown by Biudes \& Camargo [65], the efficiency of wetlands can vary according to the species of macrophytes used. Deficient performance can also be related to an increase in nutrient load, as shown by Lin et al. [66]. In fact, there is a negative relationship between the nutrient load of the inflow and the percentage of removal by the wetland.

\section{Performance of the CW}

Most of the performance data available for CW systems are from temperate regions. While the efficiency of the treatment could be considerably higher in tropical areas under certain conditions it may lead to eutrophication $[67,68]$. A wetland's efficiency can also be impaired when carrying capacity of the plants is reached. Submerged water plants are commonly covered by periphytic algae, especially with high concentration of nutrients in the water. These algae remove a large amount of nutrients, which can hamper the efficiency of the treatment; additionally, if the macrophytes are not periodically removed, the stored nutrients tend to return to the water column during plant senescence as reported by Niegel [69].

In a study by Barros et al. [70], regarding the treatment of domestic sewage with E. crassipes, the authors verified that the 
system showed better efficiency in reducing the concentration of TDS in the aerobic lake mud-obtaining removal levels between $64 \%$ (with E. crassipes) and 25\% (without macrophytes). According to the authors, this reduction was due to the surface area of $E$. crassipes roots, which retains and absorbs the materials. In Brazil, the use of CWs for treating several types of wastewater is on the rise. Scientific publications that evaluate performance of the treatments over the long term are rare, which reinforces the need for combined measures among research-funding institutions, education and research institutions, public authorities, the private sector and the communities involved. Though high, water use by fish farming is not particularly consumptive and allows for water reuse. This is crucial for water-scarce areas such as the semiarid region of Brazil, where fish farming could be integrated with agriculture, with outlets from aquaculture potentially being used to irrigate crops [15].

The constructed wetland evaluated in this article consists of an excavated tank with two aquatic macrophytes: Eichhornia crassipes and Egeria densa. From the operational point of view, it can be said that the treatment system was tested under critical conditions going through a drought period in 2015. The wetland demonstrated efficiency in the reduction of the analyzed parameters, except for total phosphorus and total nitrogen from the fish outlet, setting most of the analyzed parameters to the standards required by CONAMA Resolution 430 [7] and reducing the impact of fish farming on the receiving water body.

The removal efficiency results reveal that during the rainy season the system presented a better efficiency than in the dry season. To achieve a satisfactory result, the wetland should be associated with another complementary treatment system, such as stabilization lagoons or overflow channels. A limitation of the technique used is that its efficiency depends on seasonality. Flooding may not be a high risk in the semiarid region, but if many fish tanks release effluents at the same time, a similar effect occurs. On the other hand, in case of severe drought the operator must decide how much water can still be channeled to the wetland, first considering the fish, then the wetland. If the drought persists for a long time, the wetland may have to be discontinued temporarily.

Another limitation is that a CW needs periodic maintenance due to plant senescence while leads to decrease in water quality. During the experiment there was quick growth of macrophytes' biomass due to the semiarid climate and excess of nutrients. To improve the removal efficiency of the CW regarding total phosphorus and total nitrogen, it would be necessary to carry out management by pruning and regular harvesting bi-weekly-or maybe even weekly since in the typical climatic conditions the plants tend to enter the senescence stage more quickly compared to other regions. Another related problem is that this macrophyte is a focus of mosquitoes, among others. It is also important to make use of the biomass, since it can be part of the nutritional composition of feed for cattle, fertilize the soil and promote cost reduction, among other uses.

The relevance of the present study is that it was the first CW installed in a fish farm located in the Brazilian semiarid region. It can be useful for local fish farmers in the region to improve outlet quality and it helps the scientific community to understand the behavior of physico-chemical variables of the wastewater in a CW with the aquatic macrophytes E. crassipes and E. densa in a semiarid climate, contributing to sustainable management of aquaculture.

\section{Conclusion}

Due to water shortage in semiarid regions, it is necessary to adopt strategies to improve water use. The use of eco-friendly technologies must be prioritized to reduce the negative impacts of aquaculture. The use of constructed wetlands for effluent treatment is an alternative that if handled correctly provides economic, social and environmental benefits to assure the sustainability of aquaculture, an important economic activity, especially in semiarid regions.

So far, there is no effluent quality monitoring in most fish farms, and the cheapest and easiest way to dispose of untreated effluent is simply to return it to the reservoir. Therefore, to ensure water quality and promote the sustainable use of natural resources it is fundamental that there is an intensification of the environmental control of aquaculture activity in the semiarid region by governmental institutions. For future works it is recommended that E. crassipes must be replaced by another plant; its rapid growth related to the semiarid climate and excess of nutrients-requires frequent handling which increases maintenance costs due to hand labor.

\section{Acknowledgement}

The authors would like to thank CNPq (Brazilian Ministry of Science, Technology, Innovation and Communication), FACEPE (Foundation for the Support of Science and Technology of the State of Pernambuco, APQ 1248_3.07/15) and the INNOVATE projectInterplay among multiple uses of water reservoirs via innovative coupling of substance cycles in aquatic and terrestrial ecosystemsfinanced by BMBF (German Ministry for Education and Research, 01LL0904C) and MCTI (Brazilian Ministry for Science, Technology and Innovation, 490003/2012-5), with the following institutions: Federal University of Pernambuco, State University of Bahia and Technische Universitat Berlin.

\section{Conflict of Interest}

There is no conflict of interest.

\section{References}

1. Cna Brazil-Confederation of Agriculture and Livestock of Brazil (2015) Tilapia Production Chain. Aquaculture Assets Ed.

2. Lopes JCO (2012) Técnico em Agropecuária: piscicultura. Manual Técnico, Floriano: EDUFPI, p: 1-80.

3. Waite R, Beveridge M, Brummett R, Castine S, Chaiyawannakarn N, et al. (2014) Improving Productivity and Environmental Performance of Aquaculture. Working Paper, Installment 5 of Creating a Sustainable Food Future. Washington, DC: World Resources Institute.

4. Araújo KS, Antonnelli R, Gaydeczka B, Granato AC, Malpass GRP, et al. (2016) Advanced oxidation processes: a review of fundamentals and applications in the treatment of urban and industrial wastewaters. Rev Ambient Água 11(2): 387-401. 
5. Serafini TZ, Medeiros RP, Andriguetto Filho JM (2016) Conditions for successful local resource management: lessons from a Brazilian smallscale trawling fishery. Reg Environ Change 17(1): 201-212.

6. Brasil (2011) CONAMA Resolution № 430 Provides for conditions and standards for effluent releases, complements and amends Resolution No. 357 of March 17, 2005. In: Conselho Nacional do Meio Ambiente. Diário Oficial da União 92: 89.

7. Brasil (2005) CONAMA Resolution Provides for the classification of water bodies and environmental guidelines for their classification, as well as establishes the conditions and standards for effluent discharge, and provides other measures. In: National Council of the Environment. Diário Oficial da União, Brasília, DF 18(1): 58-63.

8. European Commission (2012) Guidance document on aquaculture activities in the context of the Natura 2000 Network.

9. Agence Française de Development (AFD), European Commission (EC) Deutsche Gesellschaft für Internationale Zusammenarbeit (GIZ) (2017) Opportunities and challenges for aquaculture in developing countries. Joint Report.

10. Sipaúba Tavares LH, Barros AF, Braga FMS (2003) Effect of floating macrophyte cover on the water quality in fish pond. Acta Scientiarium 25(1): 19-31.

11. Sipaúba Tavares LH (2013) Uso racional da água em aquicultura. Jaboticabal SP Maria de Lourdes Brandel Pp: 1-190.

12. Pachauri RK, Reisinger A (2007) Intergovernmental Panel on Climate Change-Ipcc. Climate Change 2007: Synthesis Report. Contribution of working groups I, II and III to the Fourth Assessment Report of the Intergovernmental Panel on Climate Change. Core Writing Team IPCC Geneva Switzerland, pp:1-104.

13. Siegmund Schultze M, Köppel J, Sobral MC (2015) Balancing ecosystem services and societal demands in a highly managed watershed: setup and progress of a comprehensive research project. Rev Bras Ciên Amb 36: 9-23.

14. (2015) Economic Commission for Europe-Ece, International Network of Basin Organizations-Inbo (2015) Water and Climate Change Adaptation in Transboundary Basins: Lessons Learned and Good Practices. New York United Nations Publications pp: 1-128.

15. Oliveira EG, Santos FJS (2015) Piscicultura e os desafios de produzir em regiões com escassez de água. Ciência Animal, 25(1): 133-154.

16. Otte M, Jacob DL (2006) Constructed Wetlands for Phytoremediation: Rhizofiltration, Phytostabilization and Phytoextraction. In: Mackova M, Douling D, Macek T (Eds.). Phytoremediation Rhizoremediation. Springer, Dordrecht.

17. Dong X, Reddy GB (2010) Soil bacterial communities in constructed wetlands treated with swine wastewater using PCR-DGGE technique. Bioresour Technol 101: 1175-1182.

18. Ibekwe AM, Grieve CM, Lyon SR (2003) Characterization of microbial communities and composition in constructed dairy wetland wastewater effluent. Appl Environ Microbiol 69: 5060-5069.

19. Sezerino PH, Bento AP, Decezaro ST, Magri ME, Philippi LS (2015) Experiências brasileiras com wetlands construídos aplicados ao tratamento de águas residuárias: parâmetros de projeto para sistemas horizontais. Eng Sanit Ambient (20): 1.

20. Kadlec RH, Knight RL (1996) Treatment Wetlands. Florida Lewis Publishers.

21. Salati Jr E, Salati E, Salati E (1999) Wetlands projects developed in Brazil. Water Science and Technology 40(3): 19-25.

22. Sandermann H (1994) Higher plant metabolism of xenobiotics: the "Green Liver" concept. Pharmacogenetics 4: 225-241.

23. Pflugmacher S (2015) Green Liver Concept and Green Liver Systems-A Sustainable Way for Future Water Purification. Aperito Journal of Aquatic and Marine Ecosystems 1(1): 1-15.

24. Marques EAT (2015) Green Liver System-Phytoremediation Brazil.
25. Zaniboni Filho E, Barbosa NDC, Gonçalvesm SMR (1997) Caracterização e tratamento do efluente das estações de piscicultura. Acta Scientiarum 19(2): 537-548.

26. Mees JBR (2006) Remoção de matéria orgânica e nutrientes de efluente de abatedouro e frigorifico utilizando Eichhornia crassipes e avaliação da compostagem da biomassa gerada. Master Thesis. Cascavel-PR: UNIOESTE Pp: 1-70.

27. Bitar A, Tauk Tornisielo SM, Santos AAO, Malagutti EN, Silva IM, et al. (2009) Effluent treatment of pay-to-fish in constructed wetland system. HOLOS Environment, Rio Claro 9(2): 17-35.

28. Santos AAO, Camargo AFM (2015) Constructed wetlands for treatment of harvest effluents from grow-out ponds of the Amazon river prawn. Aquaculture Research 46(11): 2676-2684.

29. Crispim MC, Vieira, ACB, Coelho SFM, Medeiros AMA, et al. (2009) Nutrient uptake efficiency by macrophyte and biofilm: practical strategies for small-scale fish farming. Acta Limnol Bras 21(4): 387-391.

30. Freitas FV (2010) Bioremediation in fish effluents using aquatic macrophytes Eichhornia crassipes (Pontederiaceae) and probiotics. Dissertation. Campina Grande-PB: UFPB P: 1-41.

31. (2010) Ibge - Brazilian Institute of Geography and Statistics Itacuruba.

32. Melo GL (2007) Estudo da qualidade da água no reservatório de Itaparica localizado na Bacia do Rio São Francisco. Master Thesis. Recife: UFPE P: 1-99.

33. Mc Knight T, Darrel H (2000) Climate Zones and Types: The Köppen System. Physical Geography. Upper Saddle River NJ: Prentice Hall Pp: 200-201.

34. (2008) Condepe/Fidem-State Agency of Planning and Research of Pernambuco Itacuruba City. Recife: CONDEPE/FIDEM.

35. Silva RF, Silva JLA, Barbosa AD (2011) Gestão do uso e reuso da água de cultivos de alevinos em Itacuruba-PE. In: Proceedings of the $14^{\text {th }}$ World Water Congress. Adaptive management of water and sustainable development. Ipojuca Porto de Galinhas, Brazil.

36. Belfort AF (2017) Producers of Itaparica already produce 100 tons of tilapia per month. JC Online.

37. Ribeiro MR, Santos JP, Silva EM, Pereira Júnior EA, Tenório MALS, et al. (2015) A piscicultura nos reservatórios hidrelétricos do Submédio e Baixo São Francisco, região semiárida do Nordeste do Brasil. Actapesca 3(1): 91-108.

38. Kubitza F (2015) Aquicultura no Brasil. Principais espécies, áreas de cultivo, rações, fatores limitantes e desafios. Panorama da Aquicultura $25(150)$.

39. Golterman HL, Clymo RS, Ohnstad MAM (1978) Methods for physical and chemical analysis of fresh water. Oxford Blackwell Scientific.

40. Koroleff F (1976) Determination of nutrients: 2 Ammonia In: Grasshoff K (Edt.), Methods of seawater analysis pp: 126-133.

41. Winkler LW (1888) Ber Deutsch Chemischen Ges. Ber Deut Che Ges 2: 2843-2855.

42. INMET-National Institute of Meteorology (2016) Historical SerieFloresta Station-A351.

43. Kadlec RH, Wallace S (2009) Treatment wetlands. (2 ${ }^{\text {nd }}$ edn.), USA.

44. Freitas FRS, Rigghetto AM, Attayde JL (2011) Suspended solids and phosphorus load in a Brazilian semi-arid reservoir. Oecologia Australis 15(3): 655-665.

45. Lautenschlager SR (2001) Modelagem do desempenho de wetlands construídos. Dissertation São Paulo: USP, Departamento de Engenharia Hidráulica e Sanitária Escola Politécnica P:1-90.

46. Turcius AE, Papenbrock J (2014) Sustainable Treatment of Aquaculture Effluents-What Can We Learn from the Past for the Future? Sustainability 6(2): 836-856.

47. Manfrinato ES (1991) 0 aguapé-fatos e fofocas. In: Problemas Ambientais Brasileiros Fundação Salim Farah Maluf Pp: 109-112. 
48. Rodella RA, Costa NV, Costa LDNC, Martins D (2006) Diferenciação entre Egeria densa e Egeria najas pelos caracteres anatômicos foliares. Planta Daninha Viçosa-MG 24(2): 211-220.

49. Cetesb-Companhia Ambiental do Estado de São Paulo (2009) Inland water quality report for the state of São Paulo. Series Reports. CETESB São Paulo: P: 1-44.

50. Minucci LV, Pinese JF, Espíndola ELG (2005) Análise limnológica de sistema semi-intensivo de criação de Leporinus macrocephalus (Pisces, Anostomidade). Biosci. J Uberlândia 21(1): 123-131.

51. Carvalho Júnior SB, Furtado DA, Dantas Neto J, Cardoso DU (2014) Sources and Physical-Chemical Quality of Water for Fish Farming in Cariri Paraibano. Revista Educação Agrícola Superior 29(1): 26-29.

52. Rotta MA, Queiroz JF (2003) Boas práticas de manejo (BPMs) para a produção de peixes em tanques-redes-Corumbá. Embrapa Pantanal P: $1-27$

53. Hussar GJ, Paradela AL, Jonas TC, Gomes JPR (2005) Constructed wetland on waste water treatment of fish water: physical and chemical quality analysis. Engenharia Ambiental Espírito Santo do Pinhal 2(1): 046-059.

54. Cavalcante DH, Sá MVC (2010) Effect of photosynthesis on Nile tilapia culture water's alkalinity. Revista Ciência Agronômica 41(1): 67-72.

55. Tundisi JG, Tundisi TM (2008) Limnologia. Oficina de Textos São Paulo: Pp: 1-631.

56. Souza WTZ, Panitz CMN, Vinatea LA (2003) Tratamento de efluentes de carcinicultura por dois wetlands artificiais pilotos, com e sem Spartina alterniflora-perspectivas de aplicação. Master Thesis. Florianópolis: UFSC Pp:1-109.

57. Casillas Hernández R, Magallón Barajas F, Portillo Clarck G, Páez Osuna F (2006) Nutrient mass balances in semi-intensive shrimp ponds from Sonora, México using two feeding strategies: trays and mechanical dispersal. Aquaculture 258(1-4): 289-298.

58. Batista AA, Meireles ACM, Andrade EM, Izidio NSC, Lopes FB, et al. (2014) Seasonal and spatial variation of the trophic state index of the Orós reservoir, Ceará, Brazil. Revista On-line 8(1): 39-48.

59. Cooke GD, Welch EB, Peterson S, Nichols SA (2005) Restoration and Management of Lakes and Reservoirs. ( $3^{\text {rd }}$ edn.), pp: 1-616.
60. Reckhow KH, Chapra SC (1983) Engineering Approaches for Lake Management: Data Analysis and Empirical Modeling. Butterworths, Boston, MA, USA.

61. Leonardo AF, Correa CFE, Baccarin AE (2011) Qualidade da água de um reservatório submetido à criação de tilápias em tanques-rede, no sul de São Paulo, Brasil. Bol Inst Pesca São Paulo 37(4): 341-354.

62. Poças CD (2015) Utilização da tecnologia de wetland para tratamento terciário: controle de nutrientes. Master Thesis. São Paulo-SP: Faculdade de Saúde Pública P: 1-93.

63. Donini CA, Germano MIS, Miguel O, Germano PML (1993) Fish, Cholera and public health. Rev Comun Cient Fac Med Vet Zootec Universidade de São Paulo São Paulo 17(1-2): 25-32.

64. Boyd CE, Queiroz J (1997) Management of sediment conditions of the bottom and the quality of water and pond effluents. In: Cyrino JEP, Urbinati EC, Fracalossi DM, Castagnolli N (Eds.), In: (2004) Special topics in tropical freshwater fish farming. Jaboticabal: Sociedade Brasileira de Aquacultura e Biologia Aquática P: 25-43.

65. Biudes JFV, Camargo AFM (2006) Use of aquatic macrophytes in the treatment of aquaculture effluents. Boletim da Sociedade Brasileira de Limnologia 38: 2-1.

66. Lin YF, Jing SR, Lee DY, Wang TW (2002) "Nutrient removal from aquaculture wastewater using a constructed wetland system". Aquaculture 209(1-4): 169-184.

67. Trang NTD, Konnerup D, Schierup HH, Chien NH, Tuan LA, et al. (2010) Kinetics of pollutant removal from domestic wastewater in a tropical horizontal subsurface flow constructed wetland system: Effects of hydraulic loading rate. Academic Search Premier 36(4): 527-535.

68. Santos BS, Costa BF, Eyng E, Câmara CD (2016) Avaliação da eficiência de um sistema de tratamento por wetland construído aplicado ao efluente de um frigorífico de suínos. Semina: Ciências Exatas e Tecnológicas Londrina 37(2): 13-22.

69. Niegel C (2014) Constructed Wetlands, Surface Flow. Jorgensen SE, Fath B (Eds.), In: Enciclopedia of Ecology. Spain, Elsevier Science (1): 3120.

70. Barros JPAA, Jimenez DMRS, Oliveira FR, Henares MNP (2015) Treatment of domestic sewage with wetland settled with Eichhornia crassipes. XII National Congress of the Environment of Poços de Caldas. Annals. Poços de Caldas, Minas Gerais, Brazil. 